\title{
The Memory of the French Centurions: Asia-Europe Connections in the Tragic Memory of Pierre Schoendoerffer's Films
}

\author{
José Maurício Saldanha Alvarez \\ Correspondence: José Maurício Saldanha Alvarez, Cultural Studies and Media Department, Universidade Federal \\ Fluminense, Brasil.
}

Received: April 14, 2019 Accepted: May 17, 2019 Online Published: May 28, 2019

doi:10.5539/res.v11n2p97

URL: https://doi.org/10.5539/res.v11n2p97

\begin{abstract}
Inspired by Pierre Nora and Maurice Halbwachs, who were French researchers of the mechanism of the memory, and Jean Larteguy, the novelist who gave a voice to the defeated French colonial soldiers, this essay explores the passage of the perilous memories of the veterans of the French Far East Expeditionary Corps, which fought in Indochina between 1945 and 1954, based on the regenerative memory of the war and of Asia and on their memories of themselves. The defeat at Dien Bien Phu resulted in the stigma of a dangerous and traumatic memory. Producers of image and rhetorical discourse, such as the French filmmaker Pierre Schoendoerffer, have undertaken acts of image making through films that transformed the humiliating defeat into a grand and redemptive tragedy. For Schoendoerffer, these acts of filmmaking constituted an unsettling and regenerative experience for both sides, creating a film production of transcultural memories connecting Asia and France.
\end{abstract}

Keywords: colonies, memory, France, Indochina, Cold War

\section{Background}

\subsection{Indochina War: Historical, Political and Military Context}

The First Indochina War was waged between the Viet Minh and France from 1945 to 1954, and it has been identified as the roots of the American War in Vietnam because after French withdrawal, the United States (US) government replaced it as the dominant power in the south of the Peninsula (Gallichio, 2012).

In France, from 1954 until the middle of 1968, the memory of the Indochina conflict was rendered accursed. In addition to public indifference, it was considered a colonial adventure undertaken by militarists, fascists, and criminals (Dalloz, 1987). The French Communist Party (PCF) harshly attacked the French Far East Expeditionary Corps (Corps Expéditionnaire Français en Extrême-Orient - CEFEO) and dedicated itself to undermining it in parliament, sabotaging it in factories, and insulting it in the press. The alliance between this group and the Viet Minh led to the perception of treason and a sense of betrayal. The PCF staged a campaign in the public press and in the streets asking that no more soldiers be sent to Indochina for a war that the communists designated as la guerre sale, or "the dirty war," a conflict that served the interest of the US imperialist strategy in Indochina (Maximin,1996).But very often the PCF itself confused the historical issues of the ongoing struggle in South-East Asia, even though it maintained its intense hostility to the war and the soldiers who did it, especially to the Foreign Legion, who believed that it was taken for ex SS Nazis.(Hargreaves,2005 ).

In 1954, the CEFEO's defeat by the communists at the battle of Dien Bien Phu resulted in a discrediting stigma for its soldiers, who returned to the metropolis amid public indifference. The name of the battle, Dien Bien Phu, which for the American press was a confrontation for the free world, became a pejorative term and a synonym for humiliation in the US and France after the defeat.

Regardless, the loss of Indochina accelerated the liquidation of the empire because France soon evacuated the colonies of Morocco and Tunisia; however, evacuating Algeria was out of the question. It was not a remote colony overseas accessible only after weeks of an arduous sea voyage. It was close enough from France, only a few hours of flight. And it was not only next; Algeria was France. Its Mediterranean coast was considered part of the territory of France from 1848 and represented on its maps (Shepard, 2006).

Most European soldiers and officers of the French colonial troops were opposed to decolonization. For them, the colonial empire was a sacred national heritage. They would not willingly submit to communists and to the American influence, and they would never accept losing Algeria as "part" of the French territory.. In fact, the huge Muslim population, an educated minority, most of which remained far from any integration with France, received a "paradoxical citizenship" 
(Aldrich, 2011).

To the veterans of the Indochinese War, memory, as Pierre Nora pointed out, was a phenomenon that seemed to assimilate emotion and magic, accommodating only the facts that suited an individual (Nora, 1997). They forgot the defeat, the hunger, and the sufferings of the war. What remained in the memory of the veterans was an idyllic memory of a place bountiful with easy women, friendly populations, and a climate endowed with beautiful natural sites. Thus, the great production of works of art, films, and books on Indochina / Vietnam should not be viewed merely as colonial nostalgia of the good old days or that of the empire but must be viewed in terms of the experience of the French colonial military through adventure, love, and loss and the efforts to modernize overseas by the "mission civilizatrice de la France," which ended tragically for them. When they revisited Vietnam, they realized that "their" Indochina existed only in their memories. There was a People's Republic of Vietnam and a beautiful, friendly, and young population that worked hard, and the Vietnamese citizens considered the war against France a turning point in history. Furthermore, the tricolor flag was no longer waving in the citadel of Hanoi, which had been transformed into a vibrant and cosmopolitan city (Aldrich, 2011).

The soldiers developed a syndrome that the French novelist Jean Larteguy $(1920$ - 2011) called the "temptation of the centurions," describing the failed attempted mutiny against General De Gaulle that determined the withdrawal of the colonies. This temptation manifested itself as a psychological instability that translated into a desire for military leadership at all costs. Defeated, the defenders of the nation became lost soldiers, or les soldats perdus, stigmatized as troublemakers by the democratic order. Their memories, both individual and collective, were transformed into what Fujitani called "perilous memories" (Fujitani et alii,2001 ). They circumvented the official memory of the French Army and the Fourth Republic and situated themselves in opposition to the French left wing politics as told and retold in the narratives (Sturken et al., 2001).

In the preface that Bernard Fall (1926-1967) wrote for Colonel Roger Trinquier's book on the French way of making revolutionary war, he evokes the lost soldiers of Jean Lerteguy's novel The Centurions (Les Centurions). The title refers to the captains in command of companies, recalling the commanders of centuries, who were the equivalent of a company in the Roman Legions that became angry and rebelled against the blind and distant power of the Roman empire when it betrayed them. As Larteguy wrote, "I shall always feel attached to those men, even if I should not break with the course they will follow and dedicate this book to the memory of all the centurions who perished so that Rome might survive" (Fall \& Trinquier, 1961). Larteguy was the author of novels that depict the essentials and nostalgia of Indochina that afflict the veterans of the French Expeditionary Corps (Dalloz, 2006). An intense and exhaustive research thesis written by M. Kathryn Edwards in 2012, The Evil Yellow, which was subsequently published as a book, supports this motif.

\section{Material and Methods}

\subsection{The Evil Yellow: Blessing or Curse of the Collective Memory?}

French novelist Jean Larteguy (1920-2011), himself a veteran of Indochina and the Korean Battalion, wrote novels whose themes involved the relation between France and Indochina and the colonial wars. A novel entitled Le mal Jaune is a narrative about the Vietnamese cities where he lived, Saigon and Hanoi, and describes his love for these cities, especially Hanoi. It is also a novel about the nostalgia of the soldiers who lost the war and were expelled from Vietnam but who felt deeply attached to this Asiatic land that no longer belonged to them, though they remained deeply rooted in it. Collectively, these combat veterans suffered a memory deficiency that became known as the "yellow evil." As Lowenthal wrote, the past "not only aids and delights; it also saddens and threatens" (Lowhenthal, 2015).

For Maurice Halbwachs (1877-1945), collective memory overlaps with individual memories, forming a process of communicating vessels. Collective memory is constructed by a set of individuals - the European CEFEO veterans - who maintain cultural axes in common despite their internal divisions. It is historic and grounded in time and space (Halbwachs, 1997). The time period is from 1945 to 1954, and the space is the entire Indochina Peninsula, including Laos and Cambodia.

In the year 1965, in the middle of struggle what Ruscio and Tignères called "the American War of Vietnam" (Ruscio \& Tignères, 2005), General Charles de Gaulle's government initiated a cautious approach to Vietnam. Playing a discreet role in the Second Indochina War, France and the Democratic Republic of Vietnam outlined economic, political, and cultural contacts. As the French public followed the American intervention in Vietnam through its perspective, the memory of the conflict was revisited. The American way was mediatized, and the French reception of the news followed the same path, though differently. Faced with the striking contrasts between them - the rich and electronic American war and the under-financed war conducted by the CEFEO - the indifference and disdain in relation to the French troops was replaced by a positive but partial revaluation. After the Paris Peace Accords of 1973 and the fall of Saigon, the reunification of Vietnam occurred under communist rule on April 30, 1975. Soon after, waves of French veterans visited Vietnam and revisited the battlefields, which had changed significantly (Edwards, 2012). 
Between 1980 and 1986, the memory of the veterans was honored, and the corpses of the 27,000 KIA were repatriated with honors. In 1993, President François Mitterrand made the first official and controversial visit by a French head of state to the Democratic Republic of Vietnam to honor the dead in Dien Bien Phu, as the author of this article can verify. For the Vietnamese, the war against France as portrayed in museums is in fact what they refer to as "a page turned" in the book of History (Edwards, 2012, 101). This was the beginning of French recognition of the political mistakes that led to the assignment of impossible missions to the CEFEO. In 2005, President Jacques Chirac decreed an official tribute to the French who died in Indochina (Journoud \& Tertrais, 2005). The First Indochina War is an integral part of the studies on decolonization and the Cold War, both of which difficult the perceptions of the conflict, though one overshadows the importance of the other. The unequivocal link between communism and the Viet Minh turned what was a local and colonial conflict into part of a world war (Edwards, 2012). Part of the myth surrounding the French presence, as argued by Kathryn Edwards, lies in the fact that if the Viet Minh fought for independence, the French fought for Vietnamese independence against the communist tyranny represented by the Viet Minh (Edwards,2012).

For Miyoshi and Ritter, the changes resulting from the post-Cold War global reality of the Asiatic context led to a qualitative change in the local historiography. Supported by the new local political alignment, which resulted in a change to the established perspectives, there was a shift in the objects of and a readjustment of the key questions related to the historiography (Jager \& Mitter,2007).

In the 1980s, the transformations were consolidated with the fall of the Berlin Wall and the disappearance of the French Communist Party. This allowed for an accommodation with Vietnam and the beginnings of a common imaginary and memorial production, resulting in cinematic co-productions, such as Régis Warnier's Indochine, winner of the 1992 Oscar for Best Foreign Film. In the same year, an act of image, or coup d'image, resulting from that strain was the Franco-Vietnamese production Dien Bien Phu.

As a cameraman in the army's cinematography service, Pierre Schoendoerffer (1928-2012) participated in the Battle of Dien Bien twice. Wounded at the beginning of the combat, he parachuted again into the besieged camp of Dien Bien Phu and joined the fate of his comrades (Ruscio \& Tignères, 2005). Captured by the People's Army of Vietnam, he wrote: "Prisoner, I went deep in human nature: Three quarters of my comrades died. I am a survivor, so a debtor" (Schoendoerffer, 1992, 100). His fictional films redeem this debt, contextualizing the fighting, and include both the antagonists and the protagonists of the struggle.

Three films have been chosen that represent the gradual metamorphosis of the memory of this war-both on the individual level and in collective representations occurring in Asia and in France. These films are Section 317 (1964), Le Crabe-Tambour (1977), and Dien Bien Phu, which brought the drama of the fortified camp to the screen and made the cultural convergence between Vietnamese memory and French memory possible. In making this film, Schoendoerffer described it as "a disturbing experience, both for them and for us" (Dien Bien Phu, 1992).

\subsection{The French Army. A Memory of Defeats}

As an entity, an army maintains an archive of both official and individual memories. According to Pierre Nora, a memory made of paper exists in museums, institutions, and libraries; however, memory is a giant and dizzying repertoire, dependent in part on stock material, without which it is impossible to remember. Memory is a bottomless repertoire which must be acknowledge (Nora, 1997, 25). The origins of the memories of trauma experienced by the CEFEO veterans are remote and do not begin at Dien Bien Phu. For example, during World War I (1914-1918), France won the war, but the price paid for victory was extremely high ( Goyet, 1972).

In 1940, the humiliating military defeat suffered by France was followed by the degrading armistice that divided the country in half. One part was occupied by the Nazis, and the other became a satellite under the Vichy regime (Jordan, 36). The army and its loyalties were similarly divided. Half remained loyal to Marshal Phillip Pétain (1856-1951), with its composition regulated by the Armistice's terms (Belle, 2007). The other half was constituted under the Free French movement, created and commanded by General Charles de Gaulle (1890-1970). He installed himself in London and reorganized his own aerial, naval, and ground forces, which fought alongside the Allies. His nationalist rhetoric preaching recovered several colonies, such as the New Hebrides, New Caledonia, Tchad, and Cameroun, whose garrisons lent support to military forces and the government in exile for the Free French movement (White, 1964). A paradox was established, with the overseas colonies having to liberate the metropolis from a totalitarianism of European origin. After the Allied landings in French North Africa, on November 8, 1942, de Gaulle realigned the movement, which gained political and military force. The Free French army had already fought with success and would become the first Allied military corps to reach the Nazi citadel of Berchtesgaden (Stout \& Yeide, 2007). Despite later victories, the stigma of 1940 still weighed on the collective memory of the army and of the country. 


\subsection{French Far East Expeditionary Corps: The Place of Memory}

At the end of 1944, the CEFEO, or French Far East Expeditionary Corps (Corps Expéditionnaire Français en Extrême-Orient), was formed. The aim was to fight against the Japanese empire and to recover occupied Indochina for France. In the following years, the troops of the Foreign Legion, Senegalese artillery, goumiers, and North African tirailleurs joined. It received battalions of colonial paratroopers, or les paras, who were members of the famous BPC (Bataillon de Parachutistes Coloniaux), a well-trained group of shock troops, and the intervention of the État-Majors (Tucker, 1964). In 1947, in turn, the paratroopers of the Foreign Legion were basically comprised of German veterans of the Wehrmacht.

The French troops were dispersed across the entire peninsula in postes, small garrisons, isolated in the vastness of the territory, some soldiers grouped around the tricolor flag, and the widespread territorial occupation spread its poorly equipped troops. The postes were commanded by a lieutenant and some soldiers from the French Union, including an allocation of supplementary Indochinese. The film 317 Section tells the odyssey of one of these small, lonely, and desperately isolated posts, whose fighting in retreat is a metaphor of the total impossibility of this war.

Returning to 1946, the relentless war, driven by the Viet Minh, began to bleed the French of combat-ready soldiers. Given that the country's constitution prohibited the sending of conscripts from the continent, the ranks of the CEFEO's casualties were composed of volunteers. In addition, the Cold War obliged France to constitute standard divisions for NATO.

One factor that seems to have contributed to disseminating a deep sympathy for the population among European soldiers was the incorporation of the Vietnamese into their units (including the Foreign Legion but not in the Legion's paratrooper battalions or in the African or North African units). In a scene from the film Diên Biên Phu, Captain Kérvegan describes Lieutenant Ky of the Vietnamese paratrooper battalion as a "puppet," a nickname coined by the Viet Minh for the Vietnamese combatants in the National Army and in French units. In a conversation with the Vietnamese military while preparing the extras, Schoendoerffer explained that some of the soldiers assigned to the film would be in French uniform and added, "You will represent the ones that you called puppets at that time." The Vietnamese official smiled and said to the filmmaker, "Sir, this is a name we no longer use." According to Jean Bodin, following its creation, the CEFEO underwent a major shift in the composition of its troops.

The strategy of incorporating an increasing number of Indochinese soldiers into its units, which not without a note of racism was called "jaunissement" (yellowing), affected 60 to 80 percent of the composition of many units. The $6^{\text {th }}$ BPC, the Bigeard Battalion, consisted of an effective force of 666 officers, non-commissioned officers, and soldiers. Of this total, 376 soldiers were Vietnamese (Delpart, 2004). Like every colonial army, the CEFEO troops sometimes used brutal methods. Torture was used and practiced in all units but had not yet reached the institutional level that it would in Algeria and was rarely discussed. During some military operations, troops burned villages, killed and raped non-combatants, and destroyed plantations and animals.

From 1950 to 1953, the First Indochina War was fought in the context of the Cold War. While speaking to Parliament, the politician Pierre Mendes-France explained that the American aid provided resources to the French Treasury that normally would accrue from exports (Tertrais, 2012). American aid financed military jet fuel, munitions, and uniforms, promoting employment in local industries and the French economy as a whole (Goyet, 1972).

\subsection{The Cold War and Indochina: Colonies and National Grandeur}

In 1944, General de Gaulle's Free France increased its size, prestige, and brilliance, which led it to seek a seat at the negotiating table for the surrender of Germany and the Japanese empire at the conflict's end (Planchais,1967); however, after 1945, the French nation was impoverished, destroyed, and torn apart by ideological divisions. Its economy was in shambles. For some segments of the French political establishment, these obstacles would only be overcome with resources derived from the colonies, which also gave the country prestige and independence (Franchini, 2012).

In Indochina, US policy would ambiguously coexist with the colonial return of the French, and while it increased, it valued itself as an alternative to France (Herring, 2008). France participated in the Korean War with two crack battalions in the dual context of a global crusade against communism and the political economy of the Cold War. Nonetheless, after the armistice in 1953, the First Indochina War stood alone, suggesting that France's time had passed. The French government under President Joseph Laniel ordered the CEFEO's new commander, General Henri Navarre (1898-1983), to find a political-military exit to the conflict (Navarre). The Navarre Plan was mishandled through errors committed by Colonel Christian de Castries, by General René Cogny, and by the general himself (Patrick Jeudi, Le rapport secret, Documentary). When the fortified field of Dien Bien Phu was organized, Vietnamese General Võ Nguyên Giáp accepted the challenge and flooded it with his battle corps of 50,000 men, which was well-served by extraordinary logistics impregnable to air strikes (Giap, 1999). After a desperate 55-day struggle on the part of the French garrison, all the 
attempts to aid it failed. President Eisenhower ultimately dismissed the use of air power against the Viet Minh, almost all of whose battle corps were there. The American government paid for the French war to acquire the most precious commodity in the world: the security of the United States of America (Stora, 2004).

\section{Discussion}

\subsection{Nation, Empire, Colonization, Decolonization}

During the nineteenth century, France constructed a new overseas power, in the order of Argelia (1830), Madagascar (1839), Gabon (1862), Tonquin (1863), and Tunisie (1881) (Marsh \& Frith, 2011). The French Empire was considered an extension of the country in remote areas. In its overseas projection, the national imagination produced acts of image and republican rhetoric (Marsh, Frith, 2011, 39).

For the members of the CEFEO, Indochina was considered part of their heritage. In the theater of colonial representations, the colony and the assimilated feel linked to the mother country. In Le Crabe-Tambour, the officer views the Vietnamese landscape with constant fascination, and Indochina is represented as a place simultaneously familiar and exotic, a seductive territory for the soldiers, in addition to an opportunity for profit in the form of wages expanded by war service overseas. Benjamin Stora explains that to the French soldiers, the seductive landscape was like a piece of the world, or a colony, that belonged to them. In contrast, for American soldiers, Vietnam was a faraway land where they felt isolated and misunderstood (Stora, 2004).

Most French military men did not feel isolated in Asia, nor did they manifest a systematic hostility toward the country's inhabitants. The river base where the flotilla of Le Crabe-Tambour is stationed more closely resembles a Vietnamese village than a European naval unit. Being a place of exchanges and memories, familiar connections are found everywhere. In this case, there are memories of convergence. For the French general and author Amédée Thévenet, there was not even one veteran of Indochina who did not harbor strong emotions for the country and its inhabitants: "Rare are those comrades who do not say an enraptured word about the beauty of the places. In discovering Indochina, they show themselves to be fascinated by the smells, by the colors, by the sounds" (Thevenet, 2009). Another veteran, a Foreign Legionnaire officer, Hélie de Saint Marc, referred to Indochina as follows: "After 1954, I seem, at times, to live in exile, far from a country where I was not born" (Thévenet, 2009). Another veteran of Dien Bien Phu, André Mengelle, said: "I returned to Vietnam three times since 1993" (Je suis retorné au Vietnam à trois reprises depuis 1993). Yet another veteran, the military doctor Sauveur Verdaguer, said: "I returned to Vietnam in 1994 as an anonymous tourist completely (...) On the other hand, I however found and appreciated the kindness of this welcoming and industrious people" (Thevenet, 2009). Jean Dens, a veteran returning to Dien Bien Phu in 1980, passed the road where he was taken prisoner and was able to recognize the places where he had spent time, surprising the guide and the Vietnamese driver: "Strange feeling; despite the suffering I endured, I keep the impression of a return to the country, and today I still keep the nostalgia" (Journoud \& Tertrais, 2013, 376). In turn, Colonel Jacques Allaire of the $6^{\text {th }}$ BPC of Bigeard, a former prisoner in Dien Bien Phu and inmate in prison death camps, returned more than ten times to the country: "I have maintained strong and deep ties with my former opponents without hatred and without bias. We, together, have smoked the pipe of peace on the top of Eliane 2, one of the key positions of Dien Bien Phu."

\subsection{Cinema: Media Place of Memory Recall}

Between 1971 and 1973, French journalists, horrified by the American bombing in Vietnam, revealed what seemed to them the ambiguity of Washington policy that undertook an imperialist strategy in Vietnam in the 1960s. Their reporting had the effect of stigmatizing what they called the incompetence of the American army, which, despite its technological power, could not overcome the Vietnamese while claiming to be bringing peace to the region (Journoud \& Tratrais, 2013).

For the European fighters of the CEFEO, memories are simultaneously Asiatic and European, at times more nostalgic for the time from their youth in Asia than from the homesickness they once felt for Europe. At least partially, the concept of transnational memory, which was developed by Chiara De Cesare and Ann Rigney (Cesare , Rigney, 2014), can be applied. In the case of the veterans of Indochina, it acts as a cultural memory that evokes a process of awakening a satisfying remembrance of the land, the countryside, and the people. For the veterans, decolonization implied a rupture and a reduction; furthermore, due to the trauma of the loss and the indifference, contempt, and hostility shown by their fellow citizens and the government whom they served, disillusionment was added to their sense of loss. The soldiers went on to represent the living carriers of a difficult past - a past within of which Schwartz and Kim speak, in his analysis of the trauma experienced in Korea and China in their struggle against Imperial Japan. A past to be forgotten because the in the case of French veterans, were representatives of an empire that prevented France from finding its place among the modern nations, and a difficult past because it was associated with violence, brutality, and defeat (Schwartz \& Kim, 2010).

In the introduction to her book, Reconciliation, Civil Society and the Politics of Memory, which analyzes the issues of appeasement and memory, Birgit Schwelling insists on the importance of the actors of transnational civil society to debate 
loss as well as of the reconciliation of forgetfulness (Schwelling, 2012). Colonization created memories of convergence experienced in a difficult past for some of the colonized. Simultaneously, France did not understand the nationalistic feelings that encouraged the Indochinese people, the ex-colonized, to rethink their memories and cultural heritage. As Colonel Le Kim of the Vietnamese army wrote to the French in 1999: "You have brought us brotherhood and equality. You have taught us the history of France, that led us to make our revolution." General Tran van Quant, General Giap's Chief of Staff, expressed his heritage with a similar nuance: "I love the French people; it has brought us a formidable culture, but I do not love France as a colonial empire (Thévenet, 2009).

\subsection{War Films and Memory}

In the case of veterans who share a common memory, although it may be segmented by military units such as the Foreign Legion, there is a common pain to be shared, whether it be physical injury from battle, defeat, or the resulting humiliation of the loss of its position in the world due to de-institutionalization. It seems that, the result may come from a phenomenon that seems to originate from what Walter Benjamin called the devaluation of experience. As if we lose the ability to share experiences in particular, experience is shared by word of mouth, and the men returning from the Indochina war seemed to return not rich but poor communicative experience, precisely because the memory that fueled this experience was cursed.( Benjamin, 1956). It is the memory and pain that make them maintain strong feelings about their object, Vietnam, an independent country, for whom the French war is right now a "page turned"; however, this object is restructured in a mediatic and imagistic way as a sum capable of deflagrating new memories. This object, in this case, is a film, which is a collective artifact.

According to Pierre Nora, memory is grounded in the specific, i.e., in objects and artifacts (Nora,); it is a renewed phenomenon of the present, whereas history is a representation of the past. Cinema has mediatized the memory acts in the US and France, creating the "concrete," which Pierre Nora reports. Thus, according to Nora, memory becomes a reflexive movement that retraces its steps to remake itself (Nora, 1997). Therefore, we reaffirm here that individual memory, and collective memory are based on an economy of supports and objects, which may include a film.

Nevertheless, the war film is part of a cultural system, and it feeds on the culture of a country. In the US, based on the legacy of its independence and consolidation, the cinematographic recovery of its war in Vietnam began in the 1970s as a method of exorcising what had been damned in that memory. The sources present in these films consist of the Western genre imbued with a spirit of jingoistic revenge. Stora calls this the winning of a war lost in Vietnam in films, pointing to its exaggerated and oneiric aesthetic (Stora, 2004).

Even in defeat, the US always seeks consensus, a distant heritage forged in the war against Great Britain. In contrast, France, the heir of a revolution that in 1789 divided the country, continues with the tradition of an ideological fracture. Unlike the US, there is no consensus in France; there will always be a fracture. If memory is plural in the US, like history is plural, then in France, history and memory are not innocent operations; they are not plural. They accuse, and they are ideological. The soldiers of the CEFEO were fascists and evil colonialists, and those who opposed them were progressive and good. Although believing in its "civilizing mission," the French nation realized that universal republicanism is nothing more than "colonial nationalism" (Stora, 2004,).

Personal and simultaneously French cinema, such as the works of Schoendoerffer, struggled to be accepted as a legitimate instrument of memory. It is within such a realm that reflexivity is practiced (Nora,). In writing about the genre of self-consciousness, Robert Stam debates the existence of realism that seems embedded in the hearts of film critics and the specialized media (Stam, 1992, 129). Hence, Schoendoerffer's films are born of a complex cultural memory that requires the support of the largest dose of realism possible due to the documentary technique. His cinema is implausible on the one hand and yet moves away from impossible mimicry on the other hand. Perhaps for this very reason, it becomes a pharmakon (in philosophy, a composite of three meanings: remedy, poison, and scapegoat) (Sherzer, 1996).

\subsection{Memory of War: Memory of a Lost Generation}

The works of Schoendoerffer are historic, although for some historians, cinema is capable of producing works of art but not works of history because films are by nature misleading artifacts; however, historical films, as Robert A. Rosenstone asserts, have invaded the classroom (Rosenstone,1995). Michael Rothberg suggests that memory is composed of different historical memories, resulting in intercultural dynamics that he calls multidirectional. In turn, what Freud calls screen memory (composed of everyday mundane images) consists of the projections that emanate from repressed memories (Rothberg, 2009).

Naomi Greene, who wrote her article before the release of films such as Indochina and Dien Bien Phu, notes that in the decades preceding the 1990s, the French produced a large number of films revisiting the colonial past. Years later, Dina Schezer asserted that such films, especially Dien Bien Phu, Indochina, and L'amant, are marked by the bias of memory (Norindr, 1996). Naomi Greene observes that for Pierre Nora, the memory of the colonial troops is profoundly linked to 
the idea of a French colonial empire. For him, in the end and thereafter, they, rather than the metropolitan troops, are the place where the national community experienced the colonial problem as a national issue (Greene \& Landy, 2000). Schoendoerffer's training as a filmmaker is due to the First Indochina War. When the French fought the humiliating and disastrous Battle of RC4 in 1950, Paris named a new commander in charge of the CEFEO, General Jean De Lattre de Tassigny (1889-1952). This brilliant and contradictory military man was prophetic in his conclusions. The first of which is the absolute impossibility of winning a war of the "third kind." Second, as an anti-communist, he supported the government of Bao Dai, Emperor of Vietnam, as a national exit policy for the conflict. Third, he supported the creation of the Vietnamese National Army (Black, 2004). With the heroic death of his son, Bernard de Lattre, he declared that the young man did not die for France but rather gave his life for Vietnam. De Lattre created a military film service that was designed to film the war as acts of image.

\section{Discussion}

\subsection{Section 317: More Documentary Than Fiction}

The analysis begins with the film Section 317. Filmed in 1964, its impactful black-and-white photography earned it an award at the Cannes Film Festival. It is the story of a small military unit that serves as a metaphor for the entire First Indochina War. The setting of the film is May 1954, and the action concurrently follows the imminent fall of the fortified camp at Dien Bien Phu. At the beginning of the narrative, an order originating from headquarters commands Section 317, a unit composed of supplementary Laotians and overseen by European junior officers, to immediately withdraw from the area threatened by the enemy's imminent advance. A young officer, the fiery and enthusiastic Lt. Torrens, played by Jacques Perrin, gives the order. With a childlike face, he is completely dedicated to his men and to his métier. In combat, he uses leather gloves to prevent his rifle from slipping from his hands. He smokes cigarette after cigarette as a method of disguising his nervousness and his sense of responsibility from his subordinates. Simultaneously, he feels the weight of the responsibility to be brave and to not dishonor the army. Bruno Cremer plays the Alsatian-origin sergeant Willsdorff, a veteran who was forced to join a Nazi Wehrmacht division on the Russian front during the German occupation of 1940-1944.

During the feverish preparations for the post's evacuation, all superfluous weight burdening the soldiers' backpacks, ranging from fruits to a piglet, is cast off. Given that the CEFEO soldiers appreciate strong drink, the Europeans obtain them in the canteen. They then begin their march in the direction of the fortified post that is to welcome them in safety. On arriving at a river, the march is halted. On the opposite bank is a small group of enemy soldiers preparing to cautiously cross the river. In the face of what appears to the lieutenant to be a small number of enemies, the soldiers open fire on them. In horror, they then discover that they have targeted the vanguard of a division of 12,000 Viet Minh soldiers, who then proceed to relentlessly harass Section 317. To escape these stubborn pursuers, the small unit engages in numerous adventures, shooting and killing its pursuers but simultaneously suffering painful losses.

After taking shelter in a village, one of their gravely wounded is treated with an opium sedative administered by a young man. Exhausted by the march, the soldiers fall asleep. In the morning, the wounded soldier dies, and the soldier who takes him to the burial location recalls the visual narrative of war documentaries. Upon finding a Viet Minh propaganda unit indoctrinating a village, they attack the position. They capture a political commissioner and chase the remainder away. Lacking ammunition and medicine, the section makes contact by radio and is rescued by air by a Dakota DC-3.

Shifting from ambushes to chases and evasive maneuvers, they finally catch sight of the station of salvation that will shelter them. At that moment, it is attacked and overrun by the enemy. Hopeless, they spot a position on the top of a hill in flames. The radio rebroadcasting the Geneva negotiations announces the fall of the fortified camp at Dien Bien Phu. Torrens and his men continue their hopeless march until in the middle of splendid natural scenery, they suffer a deadly ambush. In front of a waterfall, the lieutenant is seriously injured and lies dying. At this moment, what appears to be a surreal note is heard on the radio's speaker, as though to emphasize the uselessness of the men's sacrifice. A speech from a play in English is heard (Ruscio \& Tignères, 2005). Then, Willsdorff departs, and while off-screen, the narrator clarifies that the Alsatian died in the war in Algeria. This news is read by the main characters from the next film to be analyzed, $L e$ Crabe-Tambour.

During a stay in Vietnam, during the American War, Schoendoerffer followed one platoon, a section of the US infantry, for three weeks on search and destroy operations. The small unit was under the command of an Afro-American Lieutenant, Joseph B. Anderson. From that journey, Schoendoerffer produced the documentary entitled The Anderson Platoon, which was the Oscar winner for Best Foreign Film in 1967.

\subsection{Le Crabe-Tambour: Memories of Men Bewitched by Asia}

Le Crabe Tambour (Drummer Crab) is a film from 1977. Boasting beautiful photography in luminous colors, it documents scenes of the Arctic landscape of the Island of Saint Pierre et Miquelon. The film stages the final voyage of the 
French Navy destroyer, the Jauréguyberry, when it will be delivered for scrapping. Its commander is an officer suffering from terminal cancer. He also understands that in a way that mirrors the ship he commands, this voyage is also his final mission. The onboard medic administers sedatives to him throughout the voyage to ease his intense pain. The warship's mission is designed to aid the high-seas fishermen on the fishing banks of icy Newfoundland. All the characters in the narrative are lost soldiers, and they retain painful memories of the colonial wars fought in Indochina and Algeria. The period involved is the one in which the memory of the account is carried by the onboard medic. Given that the nature sequences are long and have been cinematically crafted by Schoendoerffer, the density of the information of the past creates a solid mortar that embeds the film in the present, or the cinematic time, as Stam describes, in which the speed of the shot depends on this information density (Stam, 1992).

During the voyage, the commander and the onboard medic, together with the engineering officer, recall the First Indochina War when they developed camaraderie with an officer of unique conduct and ethics: the Crabe-Tambour, played by Jacques Perrin. In the officers' memory of the "Crab," he is dressed in an immaculate white uniform and carries on his lap his inseparable black cat. He commands an armed transport ship within a French naval riverine division that provides supplies to the posts and military operations. Fond of music, the officer listens, enthralled, to the potpourri of notes performed by the vessel's bugler. Schoendoerffer, echoing the collective memories of the veterans, transforms the military operations into a great adventure. Even when they fight to rescue a poste under attack, the men are enjoying themselves, drinking with the local population.

During one of the adventures, the officer, the crew, and his enticing black cat participate as honored guests at a banquet held by a Vietnamese mandarin, who magisterially receives them. During the celebration, the gentleman presents to the French personnel the severed heads of the Viet Minh fighters whom his men have killed. Then, he lights a cigarette and places it in the mouth of one of the dead.

In the colonial part of the Crab's life, there is a strong impression of "Oriental exoticism" that reflects the reading of works by the writer Joseph Conrad (1857-1924), including Lord Jim (1900), Nostromo (1904), and Heart of Darkness (1902). The idyllic situation is simultaneously transformed by the growing Viet Minh offensive. The tragedy of defeat finally caves in on the protagonists. Initially, the proud and naive bugler is killed on the bow of the vessel. His body, as a military pietá, is brought by the other sailors to the pier of the modest river base. Sometime later, the Crabe is captured by the Viet Minh, and during the interrogation, his identity as an officer is discovered.

After his liberation, the Crab is demobilized; however, he does not return to France. Seduced by Vietnam, he has fallen in love with Asia. He acquires a junk and begins sailing through the waters and ports of Asia as though a new Lord Jim. He sails from one side to the other of the jade-colored waters of paradisiacal Ha Long Bay, collecting scale models of junks. He receives a visit from a destroyer's commander in his junk with trust and solid friendship between them. They philosophize, conversate, and smoke opium.

\subsection{Les Soldats Perdues: The Lost Soldier, or a Colonial War Is Also a Civil War}

On April 21 of 1961, in Algiers, the generals Raoul Salan, Maurice Challe, and Edmond Jouhaud, believing that the army would follow them, attempted a coup, known as the putsch of the generals. General de Gaulle referred, pejoratively, to this attempt as "a quarteron de généraux in retraite." In complete opposition to President de Gaulle's policy, which they regarded as the abandonment of the empire and of Algeria, the generals threatened to launch paratroopers over Paris. The army remained loyal to the government, and the putsch failed but divided the military. The Crab returns to active service during the war in Algeria, with all of the characters involved in the conflict's turbulence (Fauvet \& Planchais, 1961). At a large French naval base in Bizerte, Algeria, the old comrades must decide whether they support the maintenance of the colonial empire, that is, the road to rebellion, or the road that represents the legal basis for the modernization of France. The commander sides with loyalty to the latter, whereas the Crab and French soldiers rebels and chooses French Algeria. Arrested and brought to trial for mutiny, he breaks with the captain permanently. While the captain continues with his naval career, the Crab, pardoned, leaves the Marine Nationale and goes on to command a fishing boat.

When the destroyer enters the icy French Island of Saint Pierre et Miquelon, near Newfoundland, Canada, the sick captain is informed by the medic that the Crab is anchored nearby. In the interim, he authorizes the destroyer's sailors to enjoy the sparse amenities of the icy city, where the only source of human warmth is a veterans' bar run by a former French police officer. He and his wife receive the sailors and the veterans of the colonial wars, who drink and dance. They remember their dead, refresh their memories, and recover their past.

The onboard medic insists that the commander should seek out the Crabe to converse and to rekindle their friendship. On the ship's bridge, they locate the fishing boat, and the ship's bugler plays his favorite music on the onboard radio. After being recognized, the Crab refuses to meet with the captain. After the final farewell, with sheer radio waves in a beautiful Arctic landscape, the ships and the men depart. The dying captain returns to die and the destroyer to be dismantled. Surrounded by Arctic fog, the Crabe continues to fish. 


\subsection{Dien Bien Phu}

In 1963, the American war in Vietnam led France, governed by General de Gaulle, to play a major role in the region. It abandoned the role of actor for that of mediator (Ruscio \& Tignères, 2005). In 1966, France exhorted the combatants to seek a peaceful solution to the Indochinese conflict. At this time, France proceeded to view the American war through the narrative of its war in Indochina. Intellectuals, veterans, and the press drew comparisons. It was through the mediatized eyes of the American war that the French rediscovered their war and with it, the memory of their own soldiers, ending the nostalgia for the Indochina where they fought. Public opinion revealed its indifference toward the soldiers. In the papers of the French Press, the American soldier was described as a specialist, a paid worker who performed a dangerous job supported by abundant staff and sophisticated military hardware (Ruscio \& Tgnères,2005); however, the soldiers of the CEFEO were presented as professionals, and the French journalists still signaled that the territory where the American war was being fought was four times smaller, though they were using four times more combat-ready soldiers assisted by the strongest firepower on the face of the earth.

The French writer Jean Larteguy (1920-2011), author of novels such as The Mercenaries, The Centurions, and The Praetorians, visited Vietnam as a journalist during the era of the American war. This stay resulted in the book One Million Dollars for the Vietcong. The memory of the French war, accursed to that point, was transformed and took on the aura of a perilous idealism. Faced with this dynamic reevaluation of the memory, articles and books reevaluating the First Indochina War and the CEFEO's combatants were published.

Unified Vietnam, in the form of a communist popular republic, heir of all the wounds of the brutal war that ended in 1975, found itself helpless after the dissolution of the Soviet Union and the collapse of the Eastern European economies (Ruscio $\&$ Tigneres, 2005) in 1992. The Socialist Republic of Vietnam, still under the American embargo, sought reconciliation with its former French colonizers and enemies. The government of Vietnam assumed the film's co-production, redecorating the city of Hanoi and returning it to the picturesque colonial aspect that it boasted in 1954 to serve as an excellent background location for the battle scenes (Norindr \& Schezer, 1996).

Among the film's extras are a company of paratroopers from the French army who perform real jumps, and a brigade of the Vietnam People's Army. The film presents a young concertmaster, a violinist responsible for playing the piece Concerto de l'Adieu, composed by Georges Delerue, in front of the Hanoi symphony orchestra (Norindr \& Schezer, 1996). This piece is a composition of great nobility and emotion, the very embodiment of what will be the film's soulln the French entrenched camp, the battle begins. A cousin of the violinist, a colonial paratrooper officer recovering from a wound, Jégu de Kérvegan, played by Patrick Catalifo, attends during a rehearsal. The performance prompts him to go to a bar frequented by officers of the troops of the intervention afterwards, where he finds an old enemy, a ludicrous journalist named Howard Simpson (Donald Pleasance). Traveling by tricycle to the bar in search of a scoop, the journalist fraternizes with the French officers. For Schezer, this journalist is reminiscent of the British correspondents from Graham Greene's novel The Quiet American; however, it is believed that he better resembles the character Wormold, who is also British and middle-aged, from another Green novel, Our Man in Havana (Norinder \& Shezer, 1996). Simpson is made aware of a French veteran pilot for whom Dien Bien Phu is an aerial battle. If the runway is taken by the enemy, the field is lost. At that moment, a staff officer enters the bar with a sullen expression and bad news. Kérvegan asks why, and he confirms the battle's disastrous beginning. Kérvegan replies, telling him to calm down, that tomorrow, everything will return to normal. The other insists that the situation is grave: the strongpoint Beatrice has fallen, and Lieutenant-Colonel Gaucher, commander of the crack Foreign Legion unit, the $13^{\text {th }}$ DBLE, is annihilated in four hours of fighting. The airstrip is neutralized by artillery heretofore unseen in Indochina. Dien Bien is surrounded, its fall is a matter of time.

With those scoops in hand, Howard Simpson circulates among typical colonial characters to gather news and information that becomes material sent to his journal via Hong Kong. His main purpose is to publish his stories without the interference of French military censorship.

The film photography benefits from the expertise of Shoenrdoerffer as a documentary filmmaker. Its battle scenes are highly convincing, and the camera closely follows the unfolding fighting. One of the battle's veterans, the then-lieutenant Allaire, serves as an elderly officer of the General Staff who records the conduct of the fighting on a map in Hanoi. The film presents interesting episodes, such as one in the capital of Tonkin, where a Vietnamese nationalist journalist is seen rooting for the triumph of those who would expel him, reeducate him, or simply shoot him. There is a beautiful middle-aged Eurasian, a trafficker of opium, who has a Legionnaire lover who may be her son. A tricycle driver, a humble character despised by Simpson, becomes his friend. At the movie's end, with the fall of Dien Bien Phu confirmed, the journalist treats the driver with respect. In the field, Lieutenant Brumbrouk, played by Máxime Leroux, commander of the Senegalese artillery battery and a supporter of Isaac Newton, explains the universal law of gravity while he receives the fire from the adverse artillery and fires with his American 105 guns shooting at close range. The arrival of Major Bigeard and his crack $6^{\text {th }}$ parachute battalion relieves the position and elevates morale in Dien Bien; however, the battle does not 
end. Kérvegan, convalescing from a grave wound, parachutes in and assumes command of his company of paratroopers. Despite the incessant fighting and the desperate counterattacks, the Viet Minh tide is unstoppable.

Finally, the ceasefire occurs at 5:00 pm on May 7, 1954. In the film, a mass of Vietnamese fighters, represented by 4,000 men lent by the Army of DRV, embodies the division's strength of 50,000 besiegers, who come out of the forest and overflow the position. The opening music returns with force as a column of French prisoners parades by. Off-screen, Schoendoerffer's voice announces that two-thirds of those men will go on to die in captivity.

\subsection{Cinema and Reception: The Same Movie Is Viewed Differently by Different Viewers}

The film Dien Bien Phu is ambivalent in its results. It does not have the least pedagogical value. It serves as a lyrical farewell to Schoendoerffer's comrades in arms who perished in the war (Ruscio \& Tignéres, 2005). Schoendoerffer recovers the damned memory of the Dien Bien Phu deserters, who, taking shelter in caves on the banks of the Nam Youn River, had become the "mice of Nam Yum." They were North African, Thai, and Vietnamese soldiers who plundered supplies parachuted in to survive. "They were judged too harshly at the time," and despite their faults, "they are my comrades. They belong to the family" (Schoenderffer, Dien Bien Phu, 1954-1992). When portraying a Vietnamese paratrooper lieutenant, Schoendoerffer names him Ky, a name that symbolizes the three Ky, or regions, where the country is divided: Cochinchina in the south, Annam in the center of the peninsula, and Tonquin in the north. Lieutenant Ky endorses the allegorical function that emerges with the Vietnamese who supported a capitalist solution to the conflict (Robic Dias, 2003), an aspect that demonstrates the memory of a bloody civil war within the colonial war, or Wars of the Third Kind, as Edward Rice stresses in his book of the same name (Rice, 1990).

For others, it is treated as a grandiloquent pamphlet that renders opaque the reading of the conflict. Schoendoerffer was accused of having made a film by former fighters for veterans of the CEFEO. Because the viewers do not belong to this fraternity, which consisted of soldiers, comprising a community of memory that possesses the structures of caste functioning, the film does not allow the public to identify itself with the characters, who seem separate. Far from history, they live only in the memory of the filmmaker (Ruscio, Tignéres, 2005). Several prominent French veterans wrote indignant letters to Schoendoerffer, accusing him of belittling the truth and commending the enemy (Edwards, 2010).

This debate is a reminder that the memory of the Vietnam War in the US is equally controversial. The clashes between individual memory and the memory of the veterans and between the collective memory of the veterans' associations and the collective memory of the institutions show how pharmakon is ambiguous and can be both poison and antidote (Clark, Rowe, \& Berg,1991).

In France, an intense polemic was opened between many of the old combatants with regard to the purpose of the film. General René de Biré, president of the association of the Friends of Dien Bien Phu, ultimately confirmed that the film is great and beautiful (Ruscio, Tignéres, 2005). The president of the section of the Veterans Association of the city of Marseilles believes that Schoendoerffer did not make the film for his own purposes but rather because of the influence of the Vietnamese government, who financed part of the film's production. Furthermore, criticism is directed to the fact that of the garrison's 10,000 men, in effect, only 3,000 actually fought.

\section{Conclusion}

After 1945, a war of independence undertaken by the Viet Minh broke out on the Indochinese Peninsula, and a war of recolonization was waged by France. The Expeditionary Force sent by France was composed of multinational contingents from France and its colonies. French officers and soldiers were part of an army that had experienced disastrous victories, such as in 1914, and a catastrophic defeat in 1940. In 1945, national political currents considered the maintenance of the colonial empire to be essential, ensuring international prestige and the economic recovery of the country. At the end of this ten-year war, the French army suffered a new defeat at Dien Bien Phu and abandoned the colony to the growing US presence. With the start of the Algerian war, officers and professional soldiers who were veterans of Indochina did anything to avoid another defeat. To this end, torture became part of the military routine on a great scale. In resistance to the government's policy, the veterans rose up in an attempted coup d'état, which was suppressed, with the result that the participants were treated as mutineers and were embittered by a new defeat. They began to form a community that became the heir to a national memory that came to be cursed in the following decades.

US intervention in Vietnam, which became a brutal and disastrous war for the Asian country, led the French to reconsider its war through American intervention, which, despite all its power, did not prevent the ultimate victory of the Democratic Republic of Vietnam (DRV). In the view of General de Biré, the French fought a "poor man's war," whereas the Americans were mistaken in supposing that the all the field problems could be resolved through technology. Based on your books, it was soon realized that it was the Vietnamese people who would be the victims of another war (Tertrais \& Journoud, 2005). In the US, the defeat in Vietnam triggered a bitterness that was remedied in the 1970s by mediatization through the cinema, with its specific processes and aesthetics. In marked contrast to the French colonial 
war, in the American war, the use of the medium of television was fundamental to the American public and allowed the war's wide dissemination. The French wars were presented in their country through the cinema in edited and censored films exhibited in movie theaters. The number of televisions in 1954 was low, and in 1958, the number of television sets in France was 800,000. In 1962, at the end of the war in Algeria, there were still only 3,000,000 television sets, and broadcasting was conducted by one or two official networks controlled by the censorship of the Ministry of the Interior (Stora, 2004).

The films by Schoendoerffer, himself a veteran of Dien Bien Phu, maintain integrity as a recovery of memory. The film Section 317, with its impeccable black-and-white photography, blurs fiction and documentary techniques, showing a war with no way out in which men fight desperately against defeat. Subsequently, through the lens of a magnificent abundance of color, Le Crabe-Tambour shows the Western gaze dazzled by the Eastern landscape and its inhabitants, who entice the European fighters. The conclusion of the analysis is that the moving memory is mediatized in films, such as those by Pierre Schoendoerffer. Delphine Robic-Diaz has characterized him as "this memory filmmaker" who succeeded well in filming a French defeat and successfully dodging the narrow circle of distribution (Roubic-Diaz, 2003). In his films, everyone has room in a niche where they recover their memory, from legionaries to paratroopers, from Vietnamese "puppets" to Africans to the deserters, the "Nam Youm rats." This was the nickname of the deserters who in the midst of battle, abandoned their units by taking shelter in the caves of the banks of the Nam Youm river. By dishing out rations and medical supplies to the fighters, they were the soldiers of oblivion and shame.

In analyzing the relationship between the stories of memories of different social groups in the US, Rothberg suggests that memory is composed of different historical memories, resulting in intercultural dynamics that he calls multidirectional. In turn, what Freud calls screen memory (composed of everyday mundane images) consists of the projections that emanate from repressed memories (Rothberg, 2009).

\section{Reference}

Aldrich, R. (2011). Conclusion in Thomas, Martin. The French Colonial Mind: Violence, military encounters and colonialism. Nebraska: University of Nebraska Press.

Belle, J. L. (2007). Défaite Francaise, Um Desastre Évitable, Le 16 Juin 1940. Non a l'armistice! vol. 73. de Campagnes et Stratégies. Paris: Economica.

Benjamin, B. S. (1956). Remembering. Mind, 65, 312-331. https://doi.org/10.1093/mind/65.1.312

Berg, R., \& Rowe, J. C. (eds.). (1991). The Vietnam War and American culture. New York: Columbia University Press.

Black, J. (2004). War since 1945. London: Reaction Books.

Brocheux, P., \& Hémery, D. (1994) Indochine. La colonisation ambigue (1858-1954). Paris: La Decouverte.

Dalloz, J. (1987). Dictionaire de la guerre d'Indochine. Paris: Édition du Seuil. Paris: Armand Colin.

De Chesari, C., \& Rigney, A. (eds). (2014). Transnational memory: Circulation, articulation, scales. Berlin: De Gruyter. https://doi.org/10.1515/9783110359107

Delpart, R. (2004). Les risiers de la souffrance, 207. Paris: Michel Lafont. https://doi.org/10.3917/ehesp.zribi.2005.01.0207

Derrida, J. (1972). La Dissemination. Paris: Éditions du Seuil.

Dufour, P. (2001). La Légion en Indochine, 1945-1955. Paris: Lavauzelle.

Edwards, M. K. (2010). Le Mal Jaune: The memory of the Indochina War in France 1954-2006. (Doctoral thesis). Retrieved from: https://tspace.library.utoronto.ca/bitstream/1807/33806/11//Edwards_MauraKathryn_201011_PhD_thesis.pdf

Elgey, G. (1969). La Republique des Contradictions. Paris: Fayard.

Eric, H., Jean, L., \& Regis, W. (1992). Indochina, France, Vietnam.

Fauvet, J. (1961). La Fronde des Géneraux. Paris, Arthaud.

Franchini, P. (2012). Les Guerres d'Indochine: Tome 2, De 1949 à la Chute de Saigon. Paris: Éditions Tallandier.

Fujitani, T., White, G. M., \& Yoneyama, L. (2001) Perilous Memories. Duke and London, Duke University Press. https://doi.org/10.1215/9780822381051

Gallicchio, M. (2011). The scramble for Asia: U.S. military power in the aftermath of the Pacific War. Lanham: Rowman \& Littlefield Publishers.

Georges de Beauregard, Pierre Schoenderffer, Le Crabe-Tambour (1977). France. 
Georges de Beauregard, Pierre Schoenderffer, Section 317, France (1964).

Georges, A. (1974). Charles de Gaulle et la Guerra d'Indochine. Paris: Nouvelles Éditions latines.

Giap, G. V. N. (1999). Diên Bien Phú. 6a edition. Hanói: Éditions Thê Goi.

Goya, M. (2014). Sous le Feu: La Mort Comme Hypothèse de Travail. Paris: Tallandier, 278.

Goyet, C. L. (1972). Notre guerre d'Indochine. 2/Le Duel (1951-1954). L'Aide Americaine. Historia hors Serie, 25. Paris: Librairie Jules Tallandier.

Greene, N. (2000). "Empire as myth and memory." In: M. Lundy (Ed.). The historical film: History and memory in media. New Brunswick, New Jersey: Rutgers University Press.

Halbwachs, M. (1997). La mémoire collective. Paris: Albin Michel.

Hargraves, A. G. (2005). Memory, empire, and postcolonialism: Legacies of French colonialism. New York: Lexington Books.

Herring, (2008). The American century and beyond.U.S. Foreign Relations. 1893-2014. New York, Madison University Press.

Hirsh, M. (1997). Family frames: Photography, narrative and post memory. Harvard: Harvard University Press.

Holland, F. (2003). European decolonization 1918-1981: An introductory survey. Hampshire: Palgrave.

Jacques Kisner, Pierre Schoendorffer, Dien Bien Phu (1992). France/Vietnam.

Jager, S., \& Mitter, R. (2007). Ruptured histories: War, memory and the post-Cold War in Asia. Cambridge: Harvard University Press.

Jean-Jacques Arnaud, L'Amant (1992). France, UK, Vietnam.

Jeudi, P., Dien Bien Phu, Le Rapport Secret. Documentary. DVD, Pal, Black and White, Stéreo, 1h, French.

Jordan, N. (1997). "Reassessments. Strategy and scapegoats: Reflections of France's national catastrophe, 1940.” In: J. Blatt (Ed.). The French Defeat of 1940. Ed. Oxford: Bergan Books.

Larteguy, J. (1965). Un million de dollars le Viet. Paris: Raoul Solar.

Lavaud, L. (org) (1999). L 'Image. Paris: Garner-Flammarion.

Lowhenthal, D. (2015). The past is a foreign country. Revisited. New York: Cambridge University Press.

Marsh, K., Frith, N., \& Chabal, E. (2011). France's lost empires: Fragmentation, nostalgia, and la fracture coloniale (after the Empire; The Francophone world and postcolonial France). Plymouth: Lexington Books.

Maximin, E. R. (1996). Accommodation and resistance: The French left, Indochina and the Cold War. 1944-1954. Paris: ABC-Clio.

Nora, P. (1997). Les Lieux de Mémoire. Paris: Gallimard.

Norindr, P. (1996). "Filmic memorial and colonial blues: Indochina in contemporary French cinema." In: Dina Schezer, (Ed.). Cinema, colonization, postcolonialism: Perspectives from the French and Francophone worlds. Austin, TX: University of Texas Press.

Planchais, J. (1967). Une histoire politique de l'Armée. Paris: Seuil.

Rice, E. E. (1988). Wars of the third kind: Conflict in underdeveloped countries. Berkeley: Los Angeles; London: University of California Press.

Robic-Diaz, D. (2003). Portrait de combattants sans imagen Guerres mondiales et conflits contemporains. Paris: Presses universitaires de France, 3, 211. https://doi.org/10.3917/gmcc.211.0107

Rosestone, R. A. (1995). Visions of the past: The challenge of film to our idea of history. Cambridge: Harvard University Press.

Rothberg, M. (2009). Multidirectional memory: Remembering the Holocaust in the age of decolonization. Stanford: Stanford University Press.

Ruscio, A., \& Tignères, S. (2005). Dien Bien Phu: Mythes et Realités 1954-2004. Cinquante ans de Passions Françaises. Paris: Les Indes Savante.

Schoendoerffer, P. (1992). Diên Biên Phû, 1954/1992, de la bataille au film. Paris: Fixot/Lincoln.

Schwartz, B., \& Mikyuong, K. (2010). Northeast Asia - difficult past: Essays in collective memory. London: Palgrave 
Macmillan.

Schwelling, B. (Ed.). (2012). Reconciliation, civil society and the politics of memory: Transnational initiatives in the 20th and 21 st century. Bielefeld: Verlag. https://doi.org/10.14361/transcript.9783839419311

Shepard, T. (2008) The invention of decolonizationj. The Algerian War and the remaking of France.Ithaca\& London, Cornell University Press.

Shezer, D. (Ed.). (1996). Cinema, colonialism, postcolonialism: Perspectives from the French and Francophone world. Austin: University of Texas Press.

Stam, R. (1992). Reflexivity in film and literature: From Don Quixote to Jean-Luc Godard. New York: Columbia University Press.

Stora, B. (2004). Imaginaires de Guerre: Les Images dans les Guerres d'Algérie et du Viêt-nam. Paris: La Découverte.

Stout, M., \& Yeide, H. (2007). First to the Rhine: The $61^{\text {st }}$ army group in World War II. St. Paul: Zenith Press.

Sturken, M. (2001). Absent images of memory: Remembering and reenacting the Japanese internment. In: G.M. White, L. Yoneyama, \& T. Fujitani (Eds.). Perilous memories: The Asia Pacific War(s). Durham and London: Duke University Press. https://doi.org/10.1215/9780822381051-002

Tertrais, H., \& Journoud, P. (2012). Paroles de Dien Bien Phu. Les Survivantes Témoignent. Paris: Éditions Tallandier.

Thévenet, A. (2001). La Guerre d'Indochine. Racontée par Eux Qui l 'Ont Vécue. Paris: France-Empire.

Thomas, M. (2011). The French colonial mind: Violence, military encounters and colonialism. Nebraska: University of Nebraska Press.

Thomas, M. J., Moore, B., \& Butler, J. (2015). Crises of empire: Decolonization and Europe imperial states. London: Bloomsbury Publishing.

Thomas, M., Moore, B., \& Butler, L. J. (2015) Crises of Empire: Decolonization and Europe's Imperial States. London: Bloonsbury Publishing.

Tucker, S. C. (1964). Encyclopedia of Vietnam War: A political, social and military history. Santa Barbara, CA: ABC-CLIO, 2011.

White, D. S. (1964). Seeds of discord: de Gaulle, Free French and the Allies. Syracuse: Syracuse University Press. Movies.

\section{Copyrights}

Copyright for this article is retained by the author(s), with first publication rights granted to the journal.

This is an open-access article distributed under the terms and conditions of the Creative Commons Attribution license (http://creativecommons.org/licenses/by/4.0/). 